\title{
Prostaglandin Protects Isolated Guinea Pig Chief Cells against Ethanol Injury via an Increase in Diacylglycerol
}

\author{
Yoshitaka Konda, Hogara Nishisaki, Osamu Nakano, Kohei Matsuda, Ken Wada, Munehiko Nagao, \\ Takashi Matozaki, and Choitsu Sakamoto \\ Second Department of Internal Medicine, Kobe University School of Medicine, Kobe 650, Japan
}

\section{Abstract}

We studied cellular processes activated by prostaglandins (PG) that are involved in the protection of gastric chief cell injury estimated in terms of dye exclusion test, release of lactate dehydrogenase (LDH), or ${ }^{51} \mathrm{Cr}$ from prelabeled chief cells. Pretreatment of chief cells with $3 \times 10^{-6} \mathrm{M} \mathrm{PGE}_{2}$ or $\mathrm{PGE}_{1}$ at $37^{\circ} \mathrm{C}$ and $\mathrm{pH} 7.4$ for $15 \mathrm{~min}$ maximally reduced not only ethanol- but also taurocholic acid-caused LDH release from chief cells. PGs equipotently stimulated increases in the accumulation of diacylglycerol and cyclic AMP without elevating intracellular $\mathrm{Ca}^{2+}$ concentrations in gastric chief cells. The rank order of the potency was equal to that of PGs to reduce the injury. Pretreatment of chief cells with synthetic 1-oleoyl-2acetyl-sn-glycerol (OAG) or 12-o-tetradecanoyl phorbol 13-acetate (TPA) reduced the injury of chief cells, while $4 \alpha$-phorbol 12,13-didecanoate, an inactive phorbol ester, failed to reduce the injury and 1-(5-isouinolinylsulfonyl)-2-methylpiperazine (H7) blocked the protective action of $\mathrm{PGE}_{2}$. On the other hand, forskolin and dbcAMP had no effect on ethanol-caused LDH release and diacylglycerol formation in chief cells. These results suggest that $\mathrm{PGE}_{2}$ and $\mathrm{PGE}_{1}$ possess the direct protective action against ethanol- or taurocholic acid-caused injury in chief cells, presumably through the activation of the diacylglycerol/protein kinase $\mathrm{C}$ signaling pathway. (J. Clin. Invest. 1990. 86:1897-1903.) Key words: prostaglandin • lactate dehydrogenase

\section{Introduction}

Prostaglandins (PG) ${ }^{1}$ have been shown to possess a variety of actions, such as the stimulation of mucous and bicarbonate secretion, mucosal blood flow, and ion transport and the inhi-

Address correspondence and reprint requests to Dr. Choitsu Sakamoto, Second Department of Internal Medicine, Kobe University School of Medicine, Kusunoki-cho, Chuo-ku, Kobe 650, Japan.

Received for publication 24 January 1990 and in revised form 25 July 1990.

1. Abbreviations used in this paper: $\left[\mathrm{Ca}^{2+}\right]_{\mathrm{i}}$, intracellular free $\mathrm{Ca}^{2+}$ concentration; $\mathrm{CCh}$, carbachol; $\mathrm{CCK} 8, \mathrm{COOH}$-terminal octapeptide of cholecystokinin; dbcAMP, dibutyryl cyclic AMP; DG, 1,2-sn-diacylglycerol; $16,16 \mathrm{dmPGE}_{2}, 16,16$ dimethyl prostaglandin $\mathrm{E}_{2}$; fura-2/ AM, fura-2 acetoxymethyl; H7, 1-(5-isoquinolinylsulfonyl)-2-methylpiperazine; IBMX, isobutyl-1-methylxanthine; $\mathrm{LDH}$, lactate dehydrogenase; OAG, 1-oleoyl-2-acetyl-sn-glycerol; PDBu, phorbol 12,13-dibutyrate; $4 \alpha \mathrm{PDD}, 4 \alpha$-phorbol 12,13-didecanoate; PG, prostaglandin; TPA, 12-o-tetradecanoylphorbol 13-acetate.

J. Clin. Invest.

(C) The American Society for Clinical Investigation, Inc. 0021-9738/90/12/1897/07 \$2.00

Volume 86, December 1990, 1897-1903 bition of gastric acid secretion in the stomach (1-3). Some of the effects may contribute to reduce injury to the gastric mucosa caused by various noxious agents luminally applied in humans and experimental animals (4-6). This PG action, which seems to be independent of their inhibitory action on gastric acid secretion, is referred to as cytoprotection (7). However, in addition to the mechanisms proposed, recently available evidence has suggested that PGs may also preserve the viability of not only gastric glands but also a homogeneous population of gastric cells exposed to noxious agents in vitro (8-10). Because PGs can directly interact with and protect gastric cells in the absence of mucus, blood flow, or bicarbonate, it is reasonable to speculate that PGs exert their protective effects presumably through activating intracellular processes. However, so far pretreatment of mucous-producing cells with dbcAMP has been shown not to reduce taurocholic acid-induced injury of the cells (9).

Accordingly, to clarify the mechanism by which PGs protect gastric cells against noxious agents-induced injury, we evaluated the effects of PGs on ethanol- or taurocholic acidcaused injury of isolated chief cells prepared from guinea pig stomach. We examined whether PGs stimulate not only cyclic AMP accumulation but also any other intracellular signals in gastric chief cells and clarified what cellular events activated by PGs are related to their protective effects on chief cell injury.

\section{Methods}

Materials. ${ }^{45} \mathrm{CaCl}_{2},{ }^{51} \mathrm{Cr},\left[{ }^{3} \mathrm{H}\right]$ arachidonic acid, and cAMP assay kit were obtained from Amersham Corp. (Arlington Heights, IL). $\left[{ }^{3} \mathrm{H}\right]-$ Glycerol was obtained from ICN K\&K Laboratories Inc. (Plainview, NY). 16,16-Dimethyl prostaglandin $\mathrm{E}_{2}\left(16,16 \mathrm{dmPGE}_{2}\right)$ was donated from Upjohn Co. (Kalamazoo, MI). Other PGs were donated from Ono Pharmaceutical Co. Ltd. (Japan). Collagenase (type 1), trypsin inhibitor (type 1s), 1-oleoyl-2-acetyl-sn-glycerol (OAG), forskolin, secretin, dibutyryl cAMP (dbcAMP), fura-2 acetoxymethyl (fura-2/AM), bovine hemoglobin, 12-O-tetradecanoylphorbol 13-acetate (TPA), $\mathrm{Ca}^{2+}$ ionophore A23187, 1-(5-isoquinolinylsulfonyl)-2-methyl piperazine (H7), $4 \alpha$-phorbol 12,13-didecanoate ( $4 \alpha \mathrm{PDD}$ ), porcine pepsinogen, isobutyl-1-methylxanthine (IBMX), and taurocholic acid (sodium salt) were purchased from Sigma Chemical Co. (St. Louis, MO). $\mathrm{COOH}$-terminal octapeptide of cholecystokinin (CCK8) was donated from Squib Institute Inc. (Princeton, NJ). Percoll was obtained from Pharmacia Fine Chemicals (Piscataway, NJ). Protein assay dye reagent concentrate was obtained from Bio-Rad Laboratories (Richmond, CA). All other materials used were of the highest grade available.

Preparation of isolated guinea pig gastric chief cells. The isolated guinea pig gastric chief cells were prepared as described previously (11, 12). The fundus and corpus of the stomach removed from a male guinea pig (Hartley strain, 250-300 g) were minced and digested for 30 min at $37^{\circ} \mathrm{C}$ in a incubation medium containing $0.1 \%$ collagenase. The gastric chief cell-enriched fraction was obtained after centrifugation of the unfractionated gastric cells dispersed in Percoll solution at $30,000 \mathrm{~g}$ for $15 \mathrm{~min}$. For experiments, the chief cells were suspended and incu- 
bated at $37^{\circ} \mathrm{C}$ in an oxygenated incubation medium constituting of $128 \mathrm{mM} \mathrm{NaCl}, 1.1 \mathrm{mM} \mathrm{MgCl}{ }_{2} \cdot 6 \mathrm{H}_{2} \mathrm{O}, 4.7 \mathrm{mM} \mathrm{KCl}, 1.28 \mathrm{mM}$ $\mathrm{CaCl}_{2} \cdot 2 \mathrm{H}_{2} \mathrm{O}, 1 \mathrm{mM} \mathrm{Na} \mathrm{HPO}_{4}, 0.5 \%$ BSA, $10 \mathrm{mM}$ Hepes, $2 \% \mathrm{MEM}$ amino acid ( 50 times concentrated), $0.1 \%$ glucose and $0.01 \%$ soybean trypsin inhibitor, at pH 7.4 (HR buffer).

LDH determination. Isolated chief cells were pretreated for $15 \mathrm{~min}$ at $37^{\circ} \mathrm{C}$ in $\mathrm{HR}$ buffer containing either PG, other agents or $0.025 \%$ ethanol as a solvent unless otherwise indicated. Chief cells were then incubated in HR buffer containing indicated volume of ethanol or taurocholic acid at $37^{\circ} \mathrm{C}$ for $1 \mathrm{~h}$. The $\mathrm{LDH}$ released into the supernatant was determined by using a spectrophotometric LDH assay kit of Nihon Syoji using pyruvate as the substrate. LDH release during the incubation was expressed as a percentage of total LDH content present in the chief cells before the incubation.

Dye exclusion test. Gastric chief cells were pretreated with PGs and incubated with a noxious agent as described above. The washed chief cells were then suspended in $1 \mathrm{ml}$ of PBS and thereafter $0.1 \mathrm{ml}$ trypan blue solution $(0.4 \mathrm{~g} / \mathrm{dl})$ was added directly to the cell suspension according to the method of Phillips (13). The number of stained or nonstained cells was counted within $10 \mathrm{~min}$.

${ }^{5 I} \mathrm{Cr}$ release assay. Isolated chief cells were incubated in $\mathrm{HR}$ buffer containing $10 \mu \mathrm{Ci} / \mathrm{ml}$ of ${ }^{51} \mathrm{Cr}$ for $2 \mathrm{~h}$. The labeled cells were pretreated with PGs and incubated with ethanol for $1 \mathrm{~h}$. Thereafter, ${ }^{51} \mathrm{Cr}$ radioactivity of the cells and of the supernatant was counted with a gamma counter. The percentage of ${ }^{51} \mathrm{Cr}$ released per sample was expressed by the method previously reported (14).

Pepsinogen measurement. Chief cells were incubated at $37^{\circ} \mathrm{C}$ for $30 \mathrm{~min}$ in the presence of test agents. Thereafter pepsinogen released into the medium was measured by the method of Anson and Mirsky using acid-denatured hemoglobin as previously described (15). Pepsinogen release was expressed as a percentage of total pepsinogen content present in the chief cells before the incubation. Pepsinogen content in chief cells was measured by the method above using porcine pepsinogen (3,800 peptic units/mg) as a standard.

Measurement of intracellular free $\mathrm{Ca}^{2+}$ concentration $\left.\left(\mathrm{Ca}^{2+}\right]_{i}\right)$. $\left[\mathrm{Ca}^{2+}\right]_{i}$ of isolated chief cells was measured by the method utilizing the $\mathrm{Ca}^{2+}$-selective fluorescence indicator fura-2 essentially as described previously (11).

Measurement of initial $\mathrm{Ca}^{2+}$ influx rate. Initial $\mathrm{Ca}^{2+}$ influx rate into chief cells was measured according to the methods of Mauger et al. as described previously (16). The cells were incubated in the presence of ${ }^{45} \mathrm{CaCl}_{2}(2 \mu \mathrm{Ci} / \mathrm{ml})$ with test agents for $30,90,150$, and $210 \mathrm{~s}$ at $37^{\circ} \mathrm{C}$. The ${ }^{45} \mathrm{Ca}^{2+}$ associated with the cells was increased lineally within the range of these time points (data not shown). The initial $\mathrm{Ca}^{2+}$ influx rate was calculated by using a slope of the linear regression line of $\mathrm{Ca}^{2+}$ uptake.

Measurement of ${ }^{45} \mathrm{Ca}^{2+}$ efflux from chief cells. Chief cells were prelabeled with ${ }^{45} \mathrm{Ca}^{2+}(2 \mu \mathrm{Ci} / \mathrm{ml})$ by incubation in $\mathrm{HR}$ buffer at $\mathrm{pH} 7.4$ for $1 \mathrm{~h}$. Thereafter, the cells were incubated with test agents for indicated periods, centrifuged, and counted for the radioactivity (17).

Measurement of cyclic AMP accumulation. Chief cells suspended in HR buffer at $\mathrm{pH} 7.4$ were incubated with PGs in the presence of 0.1 mM IBMX at $37^{\circ} \mathrm{C}$. Intracellular cAMP was extracted by sonicating and boiling the chief cells in $0.02 \mathrm{~N} \mathrm{HCl}$ containing $5 \mathrm{mM}$ EDTA as described previously (18). Cyclic AMP extracted was measured by a radioimmunoassay procedure.

Assay of 1,2-sn-diacylglycerol (DG) formation. Gastric chief cells were incubated with either $\left[{ }^{3} \mathrm{H}\right]$ arachidonic acid $(2 \mu \mathrm{Ci} / \mathrm{ml})$ in $\mathrm{BSA}$ free HR buffer or $\left[{ }^{3} \mathrm{H}\right]$ glycerol $(15 \mu \mathrm{Ci} / \mathrm{ml})$ in usual $\mathrm{HR}$ buffer at $37^{\circ} \mathrm{C}$ for $2 \mathrm{~h}$. The cells were then washed, PGs or other agents were added into the cell suspensions, and the incubation was continued for the desired time interval. The reaction was stopped by the addition of 1.88 $\mathrm{ml}$ cold chloroform/methanol (2:1, vol/vol) followed by the addition of $0.62 \mathrm{ml}$ chloroform and the same volume of distilled water. To separate $\left[{ }^{3} \mathrm{H}\right] \mathrm{DG}$ by thin layer chromatography, dried lipids (dissolved in chloroform/methanol, 90:10) and authentic standards were spotted on silica gel plates activated at $110^{\circ} \mathrm{C}$ for $60 \mathrm{~min}$ and developed in the solvent system of hexane/diethylether/acetic acid (70:30:10) twice. Ra- dioactive spots were identified by phosphomolybdic acid staining, and the radioactivity in each area was determined by liquid scintillation counting $(19,20)$.

Statistical analysis. All values are given mean \pm SE. The Student's $t$ test was used for statistical evaluation. Comparisons involving more than two groups were performed by an analysis of variance. With these analysis, an associated probability ( $P$ value) of $<5 \%$ was considered statistically significant. All experiments were performed at least four times in triplicate unless otherwise indicated.

\section{Results}

We examined the effects of varying concentrations of $\mathrm{PGE}_{2}$ on ethanol-caused injury of chief cells. The incubation of chief cells with $8 \%$ ethanol for $1 \mathrm{~h}$ caused LDH release to $20.3 \pm 0.3 \%$ of total content as compared with $3.6 \pm 0.2 \%$ of total content in the absence of ethanol. However, $\mathrm{PGE}_{2}$ pretreatment lessened the LDH release in a dose-dependent manner with the maximal reduction to $15.1 \pm 0.6 \%$ at $3 \times 10^{-6} \mathrm{M}$. A half-maximal dose $\left(\mathrm{ED}_{50}\right)$ of the inhibitory effect of $\mathrm{PGE}_{2}$ on $\mathrm{LDH}$ release was $1.8 \times 10^{-7} \mathrm{M}$. $\mathrm{PGE}_{2}$ pretreatment for $15 \mathrm{~min}$ also dosedependently reduced $5 \mathrm{mM}$ taurocholic acid-caused LDH release from $21.9 \pm 0.7 \%$ to $15.9 \pm 0.6 \%$ with an $\mathrm{ED}_{50}$ of 1.6 $\times 10^{-7} \mathrm{M}$. When the chief cell viability was estimated by the percentage of trypan blue-stained cells, $\mathrm{PGE}_{2}$ similarly reduced their percentage from $56.5 \pm 0.2 \%$ to $36.0 \pm 0.3 \%$ with an $\mathrm{ED}_{50}$ of $3.2 \times 10^{-7} \mathrm{M}$. A similar dose response curve was also observed when the viability was estimated by ${ }^{51} \mathrm{Cr}$ release (Fig. 1). Therefore, we evaluated chief cell viability by measuring the release of LDH in the following experiments.

The protective effect of $\mathrm{PGE}_{2}$ against ethanol-caused injury was reduced when chief cells were pretreated at either acid or alkaline $\mathrm{pH}$ or at reduced temperature. $\mathrm{PGE}_{2}$ maximally preserved chief cell viability when the cells were pretreated at $37^{\circ} \mathrm{C}$ and $\mathrm{pH} 7.4$ (Table I). These results suggest that $\mathrm{PGE}_{2}$ protects chief cells from ethanol injury only at physiological conditions.

As compared with $\mathrm{PGE}_{2}$, other PGs such as $16,16 \mathrm{dm}$ $\mathrm{PGE}_{2}$, and $\mathrm{PGE}_{1}$ also significantly reduced ethanol-caused LDH release to $14.8 \pm 0.7 \%$ and $15.8 \pm 0.8 \%$, respectively. $\mathrm{PGA}_{2}$

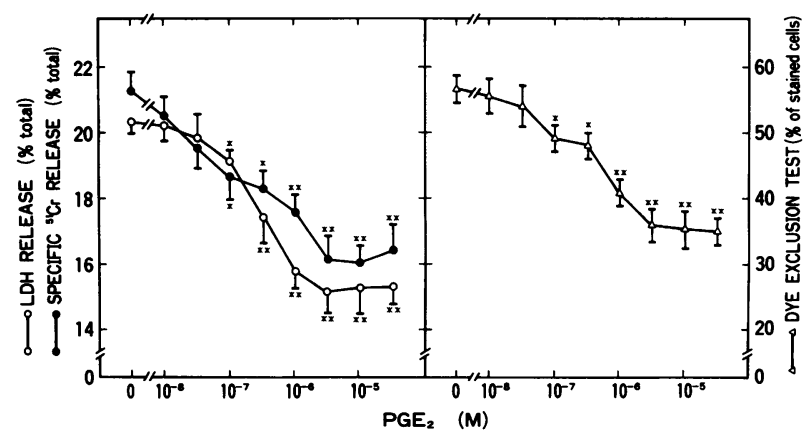

Figure 1. Effect of $\mathrm{PGE}_{2}$ pretreatment on ethanol-caused $\mathrm{LDH}$ release, ${ }^{51} \mathrm{Cr}$ release, and inability of chief cells to exclude trypan blue. Isolated chief cells were incubated with indicated concentrations of $\mathrm{PGE}_{2}$ at $37^{\circ} \mathrm{C}$ for $15 \mathrm{~min}$ and thereafter incubated with $8 \%$ ethanol for $1 \mathrm{~h}$. Chief cell injury caused by ethanol was estimated in terms of LDH release (o), ${ }^{51} \mathrm{Cr}$ release $(\bullet)$, and dye exclusion test $(\Delta)$ as described in Methods. Chief cell samples were prepared in triplicate in each experiment and results shown are mean $\pm S E$ of four separate experiments. Values indicated $\left({ }^{*} P<0.05,{ }^{* *} P<0.01\right)$ are significantly different from a respective control. 
Table I. Effects of $P G E_{2}$ Pretreatment at Different $p H$ or Temperature on Ethanol-caused LDH Release

\begin{tabular}{|c|c|c|c|c|c|}
\hline Temperature & \multicolumn{2}{|c|}{$4^{\circ} \mathrm{C}$} & \multicolumn{2}{|c|}{$16^{\circ} \mathrm{C}$} & $37^{\circ} \mathrm{C}$ \\
\hline \multicolumn{6}{|c|}{$\mathrm{PGE}_{2}$ pretreatment } \\
\hline$(-)$ & \multicolumn{2}{|c|}{$22.9 \pm 0.9$} & \multicolumn{2}{|c|}{$22.2 \pm 0.7$} & $20.5 \pm 0.6$ \\
\hline$(+)$ & \multicolumn{2}{|c|}{$22.4 \pm 1.0$} & \multicolumn{2}{|c|}{$19.0 \pm 0.8$} & $15.1 \pm 0.7$ \\
\hline \multicolumn{6}{|c|}{ Reduction of LDH } \\
\hline release (\%) & \multicolumn{2}{|c|}{$6.6 \pm 2.3$} & \multicolumn{2}{|c|}{$14.2 \pm 2.0$} & $26.5 \pm 1.7$ \\
\hline pH & 6.0 & 6.8 & 7.4 & 7.8 & 8.2 \\
\hline \multicolumn{6}{|c|}{$\mathrm{PGE}_{2}$ pretreatment } \\
\hline$(-)$ & $22.0 \pm 0.9$ & $20.9 \pm 0.8$ & $20.2 \pm 0.6$ & $21.3 \pm 0.7$ & $22.7 \pm 0.7$ \\
\hline$(+)$ & $19.2 \pm 1.0$ & $15.9 \pm 0.8$ & $14.9 \pm 0.5$ & $17.8 \pm 0.6$ & $20.1 \pm 0.7$ \\
\hline \multicolumn{6}{|c|}{ Reduction of LDH } \\
\hline release (\%) & $12.6 \pm 1.8$ & $23.5 \pm 1.4$ & $26.4 \pm 1.6$ & $16.6 \pm 1.3$ & $11.4 \pm 1.7$ \\
\hline
\end{tabular}

Chief cells were pretreated with $3 \times 10^{-6} \mathrm{M} \mathrm{PGE}_{2}$ either at the indicated temperature at $\mathrm{pH} 7.4$ or at the indicated $\mathrm{pH}$ at $37^{\circ} \mathrm{C}$ for $15 \mathrm{~min}$. Chief cells were subsequently incubated with $8 \%$ ethanol for $1 \mathrm{~h}$ at $37^{\circ} \mathrm{C}$ and $\mathrm{pH}$ 7.4. Thereafter LDH released into the medium was measured. Chief cell samples were prepared in triplicate in each experiment and results shown are mean $\pm S E$ of four separate experiments.

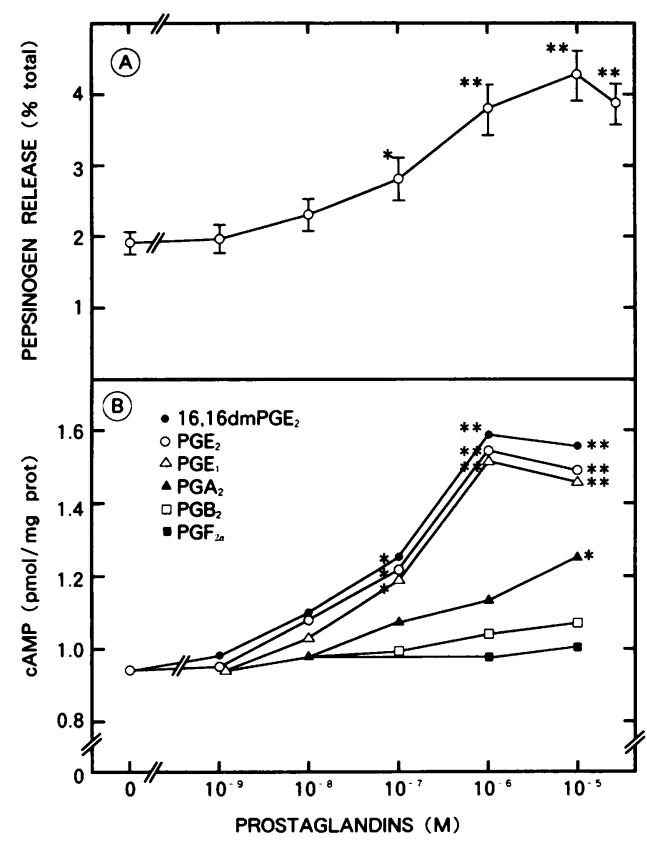

Figure 2. Effect of PGs on pepsinogen release and cAMP accumulation. $(A)$ Chief cells were incubated with indicated concentrations of $\mathrm{PGE}_{2}$ at $37^{\circ} \mathrm{C}$ for $30 \mathrm{~min}$, and thereafter pepsinogen released into the medium was measured. Chief cell samples were prepared in triplicate in each experiment and results shown are mean $\pm S E$ of four separate experiments. Chief cells in each sample $\left(5.4 \pm 1.7 \times 10^{5}\right.$ cells $)$ contain $19.7 \pm 2.1 \mu \mathrm{g}$ of pepsinogen before the incubation. $(B)$ Chief cells were incubated with indicated concentrations of $(\bullet)$

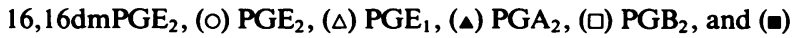
$\mathrm{PGF}_{2} \alpha$ at $37^{\circ} \mathrm{C}$ for $30 \mathrm{~min}$. Cyclic AMP extracted from chief cells was measured by radioimmunoassay. Chief cell samples were prepared in triplicate in each experiment and results shown are mean values of four separate experiments. Each SE less than $8 \%$ of mean values was omitted for clarification. Values indicated $\left({ }^{*} P<0.05,{ }^{* *} P\right.$ $<0.01)$ are significantly different from a control value. reduced $L D H$ release to $19.4 \pm 0.6 \%$, but the reduction was not statistically significant. $\mathrm{PGB}_{2}$ and $\mathrm{PGF}_{2} \alpha$ had no effect on ethanol-caused $\mathrm{LDH}$ release.

$\mathrm{PGE}_{2}$ not only reduced ethanol-caused LDH release but also stimulated pepsinogen secretion dose dependently. The maximal pepsinogen response observed at $10^{-5} \mathrm{M}$ was $4.3 \pm 0.4 \%$ total corresponding to $0.85 \pm 0.08 \mu \mathrm{g}$ pepsinogen with the calculated $\mathrm{ED}_{50}$ of $2.4 \times 10^{-7} \mathrm{M}$ (Fig. $2 \mathrm{~A}$ ). The effects of $\mathrm{PGE}_{2}$ at varying concentrations of up to $10^{-5} \mathrm{M}$ on pepsinogen secretion and ethanol-caused chief cell injury showed a similar proportional concentration dependency. Therefore, we examined what cellular processes are involved in PG-induced biological actions in chief cells. 16,16dmPGE $2, \mathrm{PGE}_{2}$, and $\mathrm{PGE}_{1}$ stimulated a dose-dependent increase in cAMP accumulation with the maximal response at $10^{-6} \mathrm{M}$ and $\mathrm{ED}_{50}$ of $1.0 \times 10^{-7}, 1.1 \times 10^{-7}$ and $1.2 \times 10^{-7} \mathrm{M}$, respectively. $\mathrm{PGA}_{2}$ had only a weak stimulatory effect and $\mathrm{PGB}_{2}$ and $\mathrm{PGF}_{2} \alpha$ had no effect on cAMP accumulation (Fig. $2 B$ ). We further examined whether pretreatment of chief cells with dbcAMP or forskolin reduces ethanol-caused LDH release from chief cells. However, ethanol-caused increase in LDH release was not reduced by the pretreatment with $10^{-5} \mathrm{M}$ forskolin or $10^{-4} \mathrm{M}$ dbcAMP at all (data not shown).

By contrast with the effects of PGs on cAMP, $3 \times 10^{-6} \mathrm{M}$ $\mathrm{PGE}_{2}$ caused no significant change in $\left[\mathrm{Ca}^{2+}\right]_{\mathrm{i}}$ of chief cells (data not shown). Furthermore, $3 \times 10^{-6} \mathrm{M} \mathrm{PGE}_{2}$ did not affect a basal rate of initial $\mathrm{Ca}^{2+}$ influx of $0.7 \pm 0.3 \mathrm{nmol} / \mathrm{min}$ per mg of chief cell protein. On the other hand, CCK8 or CCh stimulated an increase in initial $\mathrm{Ca}^{2+}$ influx rate to $4.8 \pm 0.5$ or $6.6 \pm 0.4 \mathrm{nmol} / \mathrm{min}$ per $\mathrm{mg}$ protein.

We next examined the possibility that PGs stimulate an increase in DG accumulation, thereby exerting their protective effects on chief cells. Incubation of chief cells with $3 \times 10^{-6} \mathrm{M}$ $\mathrm{PGE}_{2}$ for $15 \mathrm{~s}$ to 30 min resulted in a biphasic increase in DG accumulation in chief cells. DG response to $\mathrm{PGE}_{2}$ reached to

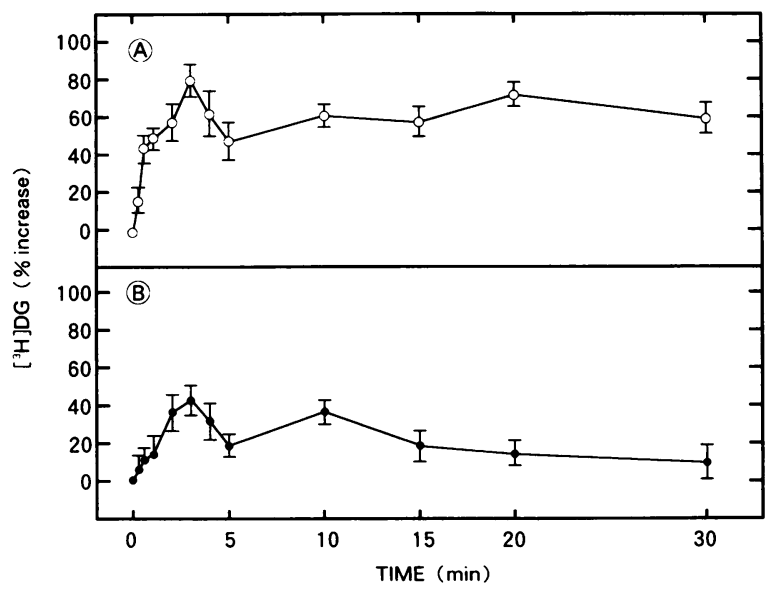

Figure 3. Effect of $\mathrm{PGE}_{2}$ on $\left[{ }^{3} \mathrm{H}\right] \mathrm{DG}$ formation. Chief cells prelabeled with $\left[{ }^{3} \mathrm{H}\right]$ glycerol $(0)$ or $\left[{ }^{3} \mathrm{H}\right]$ arachidonic acid $(\bullet)$ were incubated with $3 \times 10^{-6} \mathrm{M} \mathrm{PGE}_{2}$ at $37^{\circ} \mathrm{C}$ for indicated time periods. Thereafter the reaction was stopped as described in Methods. DG generated was collected in an organic phase, resolved, and separated by TLC. Values were expressed as percent increase over the basal value (mean values, $1,658 \pm 121 \mathrm{dpm},\left[{ }^{3} \mathrm{H}\right]$ arachidonic acid; $\left.1,884 \pm 144 \mathrm{dpm},\left[{ }^{3} \mathrm{H}\right] \mathrm{glycerol}\right)$. Samples were prepared in triplicate in each experiment and results shown are mean $\pm \mathrm{SE}$ of four separate experiments. 


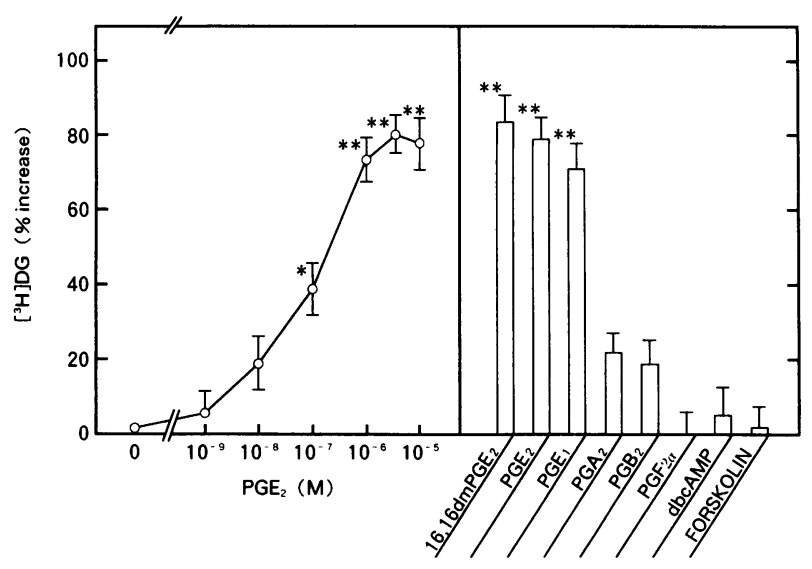

Figure 4. Effect of varying doses of PGs, dbcAMP, and forskolin on $\left[{ }^{3} \mathrm{H}\right]$ DG formation. Chief cells were prelabeled with $\left[{ }^{3} \mathrm{H}\right]$ glycerol and thereafter incubated with indicated agents at $37^{\circ} \mathrm{C}$ for $3 \mathrm{~min}$. $(A) \mathrm{Ef}$ fects of varying doses of $\mathrm{PGE}_{2}$ on DG generation. $(B)$ Effects of 3 $\times 10^{-6} \mathrm{M}$ PGs, $10^{-4} \mathrm{M}$ dbcAMP, and $10^{-5} \mathrm{M}$ forskolin. Chief cell samples were prepared in triplicate in each experiment, and results shown are mean $\pm \mathrm{SE}$ of four separate experiments. Values indicated $\left({ }^{*} P<0.05,{ }^{* *} P<0.01\right)$ are significantly different from control.

the first peak value at $3 \mathrm{~min}$ with $80 \pm 4 \%$ increase above a basal level in $\left[{ }^{3} \mathrm{H}\right]$ glycerol-labeled chief cells. $\mathrm{PGE}_{2}$ further stimulated an increase in DG accumulation with the second peak at $20 \mathrm{~min}$. DG accumulation was consistently sustained above a base level for at least $30 \mathrm{~min}$. A biphasic increase in DG accumulation in a similar time course was also observed in response to $3 \times 10^{-6} \mathrm{M} \mathrm{PGE}_{2}$ in chief cells prelabeled with $\left[{ }^{3} \mathrm{H}\right]$ arachidonic acid (Fig. 3).

This increase in DG accumulation at 3 min was dependent on either doses of $\mathrm{PGE}_{2}$ or PGs used. The maximal increase in DG in response to $\mathrm{PGE}_{2}$ was observed at $3 \times 10^{-6} \mathrm{M}$ with an $\mathrm{ED}_{50}$ of $1.0 \times 10^{-7} \mathrm{M}$ (Fig. 4). $16,16 \mathrm{dmPGE}_{2}$ or $\mathrm{PGE}_{1}$ at 3 $\times 10^{-6} \mathrm{M}$ almost equally stimulated an increase in DG accumulation, but $\mathrm{PGA}_{2}, \mathrm{PGB}_{2}$, or $\mathrm{PGF}_{2} \alpha$ at $3 \times 10^{-6} \mathrm{M}$ did not significantly stimulate the increase in DG accumulation. Furthermore, $10^{-4} \mathrm{M}$ dbcAMP or $10^{-5} \mathrm{M}$ forskolin had no stimulatory effect on DG accumulation (Fig. 4).

Therefore, we investigated the role of DG/protein kinase C signaling pathway for the protection of chief cells from ethanol injury by PGs. Pretreatment of chief cells for $15 \mathrm{~min}$ with varying doses of OAG, a synthetic diacylglycerol, which has been shown to activate protein kinase $C$ directly (21), reduced ethanol-caused LDH release from chief cells in a dose-dependent manner (Fig. 5 A). TPA or PDBu, when added instead of OAG into pretreatment medium also reduced ethanol-caused LDH release dose dependently. By contrast, $4 \alpha \mathrm{PDD}$, an inactive phorbol ester (22), did not cause any reduction of ethanol-caused LDH release (Fig. 5 B). TPA or PDBu only at a high dose of $50 \mathrm{nM}$ also failed to reduce ethanol-caused LDH release. When chief cells were pretreated with $\mathrm{PGE}_{2}$ in the presence of $\mathrm{H} 7$, a protein kinase $\mathrm{C}$ inhibitor (23), $\mathrm{H} 7$ reversed the reduction of ethanol-caused LDH release by $\mathrm{PGE}_{2}$ (Fig. $5 C$ ).

When chief cells were pretreated with varying doses of OAG plus $10^{-4} \mathrm{M}$ dbcAMP, dbcAMP did not affect the protective action of OAG or the chief cell injury at all (Fig. $6 \mathrm{~A}$ ). On the other hand, simultaneous pretreatment of chief cells with OAG plus $10^{-7} \mathrm{M} \mathrm{Ca}^{2+}$ ionophore A23187 significantly reversed the reduction of ethanol-caused LDH release by OAG (Fig. $6 B$ ). Even if chief cells were pretreated with varying doses of OAG plus $3 \times 10^{-6} \mathrm{M} \mathrm{PGE}_{2}$, additive effects on the reduction of LDH release were not observed (Fig. $6 C$ ). Pretreatment of chief cells with $10^{-7} \mathrm{M} \mathrm{CCK8}$, another pepsinogen releasing agonist which has been shown to stimulate polyphosphoinositides breakdown in chief cells (17), also maximally reduced $\mathrm{LDH}$ release from a control value of $20.3 \pm 0.3 \%$ to $18.2 \pm 0.5 \%$, but the reduction was approximately one-third of that obtained with $10^{-4} \mathrm{M}$ OAG or $3 \times 10^{-6} \mathrm{M} \mathrm{PGE}_{2}$.

Because $\mathrm{Ca}^{2+}$ ionophore blocked the protective effect of OAG on chief cell injury, we considered the possibility that OAG exerts the protective effect by increasing $\mathrm{Ca}^{2+}$ efflux from chief cells. $2.5 \times 10^{-5} \mathrm{M}$ OAG or $3 \times 10^{-6} \mathrm{M} \mathrm{PGE}_{2}$ significantly stimulated $\mathrm{Ca}^{2+}$ efflux from chief cells prelabeled with ${ }^{45} \mathrm{Ca}^{2+}$ at 5-15 min of incubation. On the other hand, $10^{-4} \mathrm{M} \mathrm{dbcAMP}$ did not affect $\mathrm{Ca}^{2+}$ efflux from chief cells at all (Fig. 7).

\section{Discussion}

In the present study by using isolated gastric chief cells, we confirmed previous reports which suggest that PGs directly

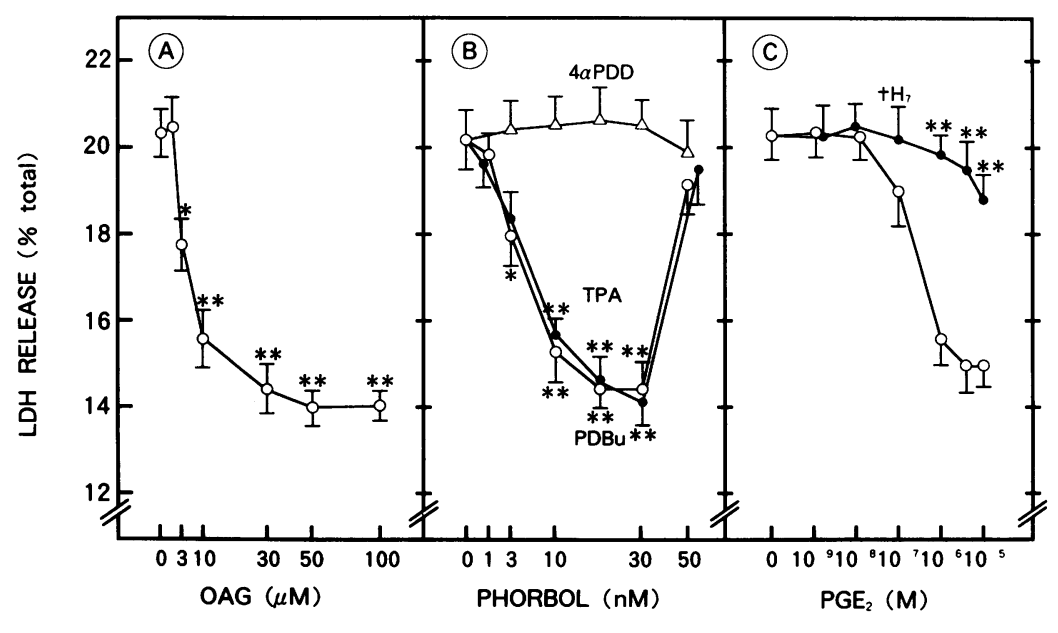

Figure 5. Effects of agents which may affect protein kinase $\mathrm{C}$ activity on ethanol-caused $\mathrm{LDH}$ release from chief cells. Isolated chief cells were pretreated with varying concentrations of $(A)$ OAG $(O),(B)$ phorbols ([0] PDBu, [॰] TPA, [ $\Delta$ ] 4 $\alpha$ PDD) or $(C)$ $\mathrm{PGE}_{2}$ in the presence $(\bullet)$ or absence $(0)$ of $5 \times 10^{-5}$ $\mathrm{M} \mathrm{H7}$ at $37^{\circ} \mathrm{C}$ for $15 \mathrm{~min}$ and subsequently incubated with $8 \%$ ethanol. Thereafter, LDH released into the medium was measured. Chief cell samples were prepared in triplicate in each experiment and results shown are mean $\pm \mathrm{SE}$ of four separate experiments. In $A$ and $B$, values indicated $\left({ }^{*} P<0.05,{ }^{* *} P\right.$ $<0.01)$ are significantly different from a control value obtained without OAG or phorbols. In $C$, values indicated $\left({ }^{* *} P<0.01\right)$ are significantly different from those without $\mathrm{H} 7$ at respective $\mathrm{PGE}_{2}$ concentrations. 


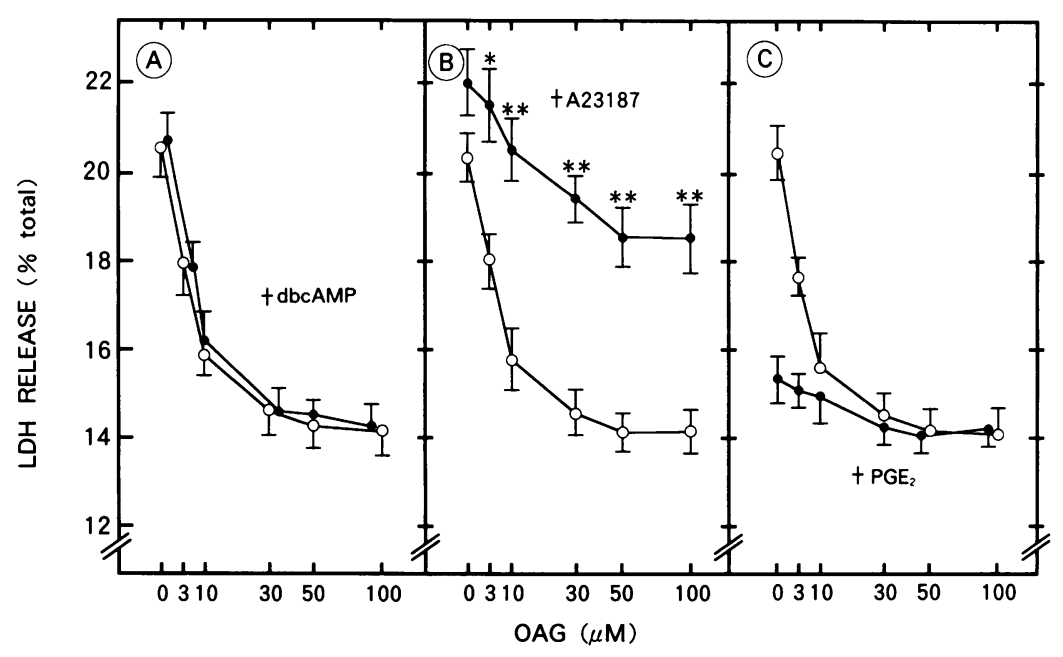

Figure 6. Combined effects of $\mathrm{OAG}$ with either dbcAMP, A23187, or $\mathrm{PGE}_{2}$ on ethanol-caused LDH release. Chief cells were pretreated with varying concentrations of OAG (O) plus either $(A) 10^{-4} \mathrm{M}$ $\operatorname{dbcAMP}(\bullet),(B) 10^{-7} \mathrm{M} \mathrm{A} 23187(\bullet)$, or $(C) 3 \times 10^{-6}$ $\mathrm{M} \mathrm{PGE} 2(\bullet)$ at $37^{\circ} \mathrm{C}$ for $15 \mathrm{~min}$. The cells were subsequently incubated with $8 \%$ ethanol for $1 \mathrm{~h}$. Chief cell samples were prepared in triplicate in each experiment and results shown are mean $\pm \mathrm{SE}$ of four separate experiments. In $B$, values indicated $\left({ }^{*} P<0.05\right.$, $\left.{ }^{* *} P<0.01\right)$ are significantly different from respective control values obtained without A23187. protect gastric cells from injury caused by noxious agents. Furthermore, we extended the previous studies in vitro and provided new data on the possible mechanism by which PGs protect chief cells directly. In the present study, $\mathrm{PGE}_{2}$ dose dependently reduced ethanol-caused increases in percentage of trypan blue-stained chief cells and release of cytoplasmic enzyme $\mathrm{LDH}$ and ${ }^{51} \mathrm{Cr}$ from prelabeled chief cells. The methods we used to evaluate the degree of chief cell injury quantitatively limit the estimation of cellular viability and function. However, previous studies have also suggested by using a scanning electron microscopy that the measurement of leaked LDH is a sensitive and accurate index of ethanol-caused injury to the gastric chief cell plasma membranes and $\mathrm{PGE}_{2}$ pretreatment preserves the structural integrity of not only plasma

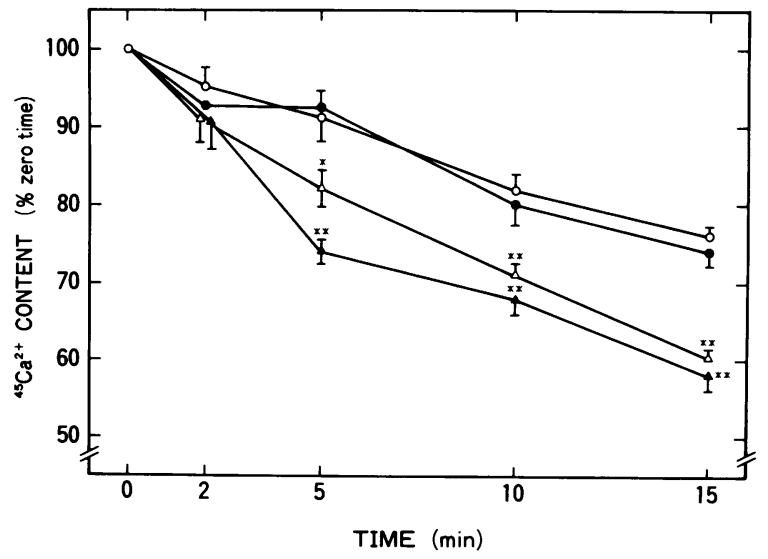

Figure 7. Effects of $\mathrm{PGE}_{2}$, OAG or dbcAMP on ${ }^{45} \mathrm{Ca}^{2+}$ efflux from chief cells prelabeled with ${ }^{45} \mathrm{Ca}^{2+}$. Chief cells prelabeled with ${ }^{45} \mathrm{Ca}^{2+}$ were incubated with $3 \times 10^{-6} \mathrm{M} \mathrm{PGE}_{2}(\Delta), 2.5 \times 10^{-5} \mathrm{M}$ OAG ( $\left.\Delta\right)$, or $10^{-4} \mathrm{M}$ dbcAMP ( $\bullet$ ) for the indicated periods. (O) Control values. Triplicate chief cell samples were then centrifuged and the radioactivity associated with the cells was counted. The ${ }^{45} \mathrm{Ca}^{2+}$ efflux was expressed as the percent radioactivity of the cells before the incubation. Results shown are mean $\pm \mathrm{SE}$ of four separate experiments. Values indicated $\left({ }^{*} P<0.05,{ }^{* *} P<0.01\right)$ are significantly different from control values at respective time points. membranes but also subcellular organelles in most chief cells exposed to ethanol $(8,24)$. Therefore, present results suggest that our methods utilized detected chief cell injury and $\mathrm{PGE}_{2}$, at least in part, effectively protected ethanol- or taurocholic acid-caused injury of chief cells.

We showed in the present study that the maximal protective effect was observed when chief cells were pretreated with 3 $\times 10^{-6} \mathrm{M} \mathrm{PGE}_{2}$ at $37^{\circ} \mathrm{C}$ and $\mathrm{pH} 7.4$, but the protection was reduced when the pretreatment was carried out at $4^{\circ} \mathrm{C}$. These results suggest that $\mathrm{PGs}$ may activate intracellular biochemical events thereby causing the protection of chief cells. Several lines of evidence suggest that PGs exert their protective effects on chief cells presumably through the activation of diacylglycerol/protein kinase $\mathrm{C}$ signaling pathway.

First, $\mathrm{PGE}_{2}$ stimulated an increase in the accumulation of diacylglycerol in gastric chief cells prelabeled with $\left[{ }^{3} \mathrm{H}\right]$ arachidonic acid or $\left[{ }^{3} \mathrm{H}\right]$ glycerol in a dose-dependent manner. The $E_{50}$ of $\mathrm{PGE}_{2}$ to cause the protection of chief cells is very close to the $\mathrm{ED}_{50}$ of $\mathrm{PGE}_{2}$ to generate diacylglycerol. Furthermore, the rank order of potency of various PGs to generate diacylglycerol in chief cells is parallel with that of various PGs in reducing ethanol-caused injury. It is well known that diacylglycerol-activated protein kinase $\mathrm{C}$ plays a crucial role for a variety of biological actions in a number of cell types (25).

Second, not only OAG but also TPA, a phorbol ester which has been shown to activate protein kinase $\mathrm{C}$ apparently by substituting for diacylglycerol $(21,22)$, effectively reduced chief cell injury in a dose-dependent manner. On the other hand, $4 \alpha \mathrm{PDD}$, an inactive phorbol ester which does not bind to or activate protein kinase $C(22)$, did not show any protective effect on ethanol-caused injury. Furthermore, $\mathrm{H} 7$ reduced the protective action of $\mathrm{PGE}_{2}$, suggesting that protein kinase $\mathrm{C}$ may be involved in the action of $\mathrm{PGE}_{2}$. Although at present we do not know yet why TPA at a very high dose failed to protect chief cell injury, TPA itself at high doses may be cytotoxic.

Third, although PGs stimulated an increase in cAMP accumulation in gastric chief cells, cAMP-dependent signaling pathway does not appear to be involved in PGs protection of chief cell injury. When chief cells were pretreated with forskolin at $10^{-5} \mathrm{M}$ which has been shown to stimulate an increase in the accumulation of cAMP in chief cells (16), it failed to re- 
duce the extent of chief cell injury caused by ethanol. DbcAMP at $0.1 \mathrm{mM}$ also did not show any protective effect on chief cell injury.

Fourth, PGs did not stimulate any increase in cytosolic free $\mathrm{Ca}^{2+}$ concentrations and initial $\mathrm{Ca}^{2+}$ influx rate in gastric chief cells. On the other hand, either $\mathrm{PGE}_{2}$ or OAG stimulates $\mathrm{Ca}^{2+}$ efflux at 5-15 min of incubation. Moreover, $\mathrm{Ca}^{2+}$ ionophore, when added into preincubation medium in the presence of OAG, partially inhibited the protective effect of OAG on ethanol-caused chief cell injury. Therefore, an increase in $\left[\mathrm{Ca}^{2+}\right]_{\mathrm{i}}$ in chief cells may negatively affect the protective action of OAG against chief cell injury and OAG-induced chief cell protection may be due to its effect on $\mathrm{Ca}^{2+}$ efflux. However, further works are clearly required to clarify whether $\mathrm{PGE}_{2-}$ or OAG-induced increase in $\mathrm{Ca}^{2+}$ efflux is really involved in the protection of chief cells exposed to noxious agents. Of interest is the observation that although CCK8 causes polyphosphoinositide breakdown thereby producing inositol phosphate and diacylglycerol in gastric chief cells (16), CCK8 at a maximally effective concentration for pepsinogen secretion does not protect chief cells from ethanol-caused injury to the extent which PGs do. An increase in $\left[\mathrm{Ca}^{2+}\right]_{\mathrm{i}}$ stimulated by CCK 8 may also negatively affect the endogenously generated diacylglycerolprovoked protection.

In general, diacylglycerol has been shown to be derived from the polyphosphoinositide breakdown which is considered to be stimulated by phospholipase $\mathrm{C}$ activation by extracellular signals (26). However, in the present study, we were not able to observe any increase in $\left[\mathrm{Ca}^{2+}\right]_{i}$ in chief cells. We have previously shown that $\mathrm{Ca}^{2+}$ mobilization can be observed in gastric chief cells when polyphosphoinositide breakdown is occurred by the stimulation of cholecystokinin (16). Therefore, PGs seem not to stimulate polyphosphoinositide breakdown to generate diacylglycerol in chief cells, although we can not completely exclude the possibility that diacylglycerol is generated in part from hydrolysis of inositol containing phospholipids (27). At present, we can not account for how PGs stimulate an increase in the accumulation of diacylglycerols in chief cells, but these data may be consistent with the observations that in some cells not all of the stimulated diacylglycerol can be derived from the hydrolysis of polyphosphoinositide $(20,28)$. The mechanism by which PGs stimulate an increase in DG accumulation in chief cells is currently under investigation.

One note of caution that we must consider in interpreting our findings is that the cell preparations used for the present study consisted of $95 \%$ chief cells in our best preparation. Accordingly, it is possible that the observed changes in diacylglycerol accumulation occurred in non-chief cells contaminating our preparations. However, the correlation between alterations in these parameters and PG-induced change in pepsinogen secretion suggests that the events are closely linked, probably within chief cells. Confirmation of this linkage requires additional studies in chief cells or other cell preparations of greater purity.

In conclusions, besides various effects of $\mathrm{PGs}$ in vivo, $\mathrm{PGE}_{2}$ and $\mathrm{PGE}_{1}$ seem to possess the direct protective action against ethanol- or taurocholic acid-caused injury in guinea pig chief cells, presumably through the activation of diacylglycerol/protein kinase $\mathrm{C}$ signaling pathway.

\section{References}

1. Cheung, L. Y. 1980. Topical effects of 16,16 dimethyl prostaglandin $\mathrm{E}_{2}$ on gastric blood flow in dogs. Am. J. Physiol. 238:G514G519.

2. Miller, T. A. 1983. Protective effects of prostaglandins against gastric mucosal damage: current knowledge and proposed mechanisms. Am. J. Physiol. 245:G601-G623.

3. Lichtenberger, L. M., L. A. Graziane, E. J. Dial, B. D. Butler, and B. A. Hills. 1983. Role of surface-active phospholipids in gastric cytoprotection. Science (Wash. DC). 219:1327.

4. Ohno, T., H. Ohtsuki, and S. Okabe. 1985. Effects of 16,16-dimethyl prostaglandin $E_{2}$ on ethanol-induced and aspirin-induced gastric damage in the rat. Gastroenterology. 88:353-361.

5. Robert, A., J. E. Nezamis, C. Lancaster, and A. J. Hanchar. 1979. Protection by prostaglandins in rat. Prevention of gastric necrosis produced by alcohol, $\mathrm{HCl}, \mathrm{NaOH}$, hypertonic $\mathrm{NaCl}$, and thermal injury. Gastroenterology. 77:433-443.

6. Tarnawski, A., D. Hollander, J. Stachura, B. Klimczyk, T. Mach, and J. Bogdal. 1986. Prostaglandin protection of the human gastric mucosa against alcohol-induced injury. Scand. J. Gastroenterol. 21:165-169.

7. Robert, A. 1979. Cytoprotection by prostaglandins. Gastroenterology. 77:761-767.

8. Tarnawski, A., T. Brzozowski, I. J. Sarfeh, W. J. Krause, T. R. Ulich, H. Gergely, and D. Hollander. 1988. Prostaglandin protection of human isolated gastric glands against indomethachin and ethanol injury. J. Clin. Invest. 81:1081-1089.

9. Terano, A., S. Ota, T. Mach, H. Hiraishi, J. Stachura, A. Tarnawski, and K. J. Ivey. 1986. Prostaglandin protects against taurocholate-induced damage to rat gastric mucosal cell culture. Gastroenterology. 92:669-677.

10. Cherner, J. A., L. Naik, A. Tarnawski, T. Brzozowski, J. Stachura, and G. Singh. 1989. Ability of prostaglandin to reduce ethanol injury to dispersed chief cells from guinea pig stomach. Am. J. Physiol. 256:G704-G714.

11. Sakamoto, C., T. Matozaki, M. Nagao, H. Nishisaki, and S. Baba. 1987. Regulation of free cytosolic $\mathrm{Ca}^{2+}$ in the isolated guinea pig gastric chief cells. Biochem. Biophys. Res. Commun. 142:865-871.

12. Raufman, J., V. E. Satliff, D. K. Kasbebar, R. T. Jensen, and J. D. Gardner. 1984. Pepsinogen secretion from dispersed chief cells from guinea pig stomach. Am. J. Physiol. 247:G95-G104.

13. Phillips, H. J. 1973. Dye exclusion tests for cell viability. In Tissue Culture Methods and Applications. P. F. Krause and M. K. Patterson, editors. Academic Press, Inc., New York. 406-408.

14. Terano, A., T. Mach, J. Stachura, A. Tarnawski, and K. J. Ivey. 1984. Effect of 16,16 dimethyl prostaglandin $E_{2}$ on aspirin induced damage to rat gastric epitherial cells in tissue culture. Gut. 25:19-25.

15. Anson, M. L., and A. E. Mirsky. 1932. The estimation of pepsin with hemoglobin. J. Gen. Physiol. 16:59-63.

16. Matozaki, T., C. Sakamoto, M. Nagao, H. Nishizaki, Y. Konda, and S. Baba. 1988. Involvement of $\mathrm{Ca}^{2+}$ influx in $\mathrm{F}^{-}$-stimulated pepsinogen release from guinea pig gastric chief cells. Biochem. Biophys. Res. Commun. 152:161-168.

17. Dormer, R. L., J. H. Poulsen, V. Licko, and J. A. Williams. 1981. Calcium fluxes in isolated pancreatic acini: effects of secretagogues. Am. J. Physiol. 240:G38-G49.

18. Sakamoto, C., T. Matozaki, M. Nagao, and S. Baba. 1987. Coupling guanine nucleotide inhibitory protein to somatostatin receptor on pancreatic acinar membrane. Am. J. Physiol. 253:G308G314.

19. Kifer, O., and E. M. Brown. 1988. Relationship between diacylglycerol levels and extracellular $\mathrm{Ca}^{2+}$ in dispersed bovine parathyroid cells. Endocrinology. 123:2723-2729.

20. Farese, R. V., T. S. Konda, J. S. Davis, M. L. Standaert, R. J. Potlet, and D. R. Coope. 1987. Insulin rapidly increases diacylglycerol 
by activating de novo phosphatidic acid synthesis. Science (Wash. DC). 236:586.

21. Kishimoto, A., Y. Takai, K. Kaibuchi, K. Sano, U. Kikkawa, and Y. Nishizuka. 1980. Activation of calcium and phospholipid-dependent protein kinase by diacylglycerol, its possible relation to phosphatidylinositol turnover. J. Biol. Chem. 255:2273-2276.

22. Castagna, M., Y. Takai, K. Kaibuchi, K. Sano, U. Kikkawa, and Y. Nishizuka. 1982. Direct activation of calcium-activated phospholipid-dependent protein kinase by tumor pormoting phorbol ester. J. Biol. Chem. 257:7847-7851.

23. Hidaka, H., M. Inagaki, S. Kawamoto, and Y. Sasaki. 1984. Isoquinoline-sulfonamides, novel and potent inhibitors of cyclic nucleotide dependent protein kinase and protein kinase C. Biochemistry. 23:5036-5041.
24. Whittle, J. R. B., and G. Steel. 1985. Evaluation of the protection of rat gastric mucosa by a prostaglandin analog using cellular enzyme marker and histologic technique. Gastroenterology. 88:315327.

25. Nishizuka, Y. 1984. The role of protein kinase $C$ in cell surface signal transduction and tumor promotion. Nature (Lond.). 308:693695.

26. Berridge, M. J. 1984. Inositol trisphosphate and diacylglycerol as second messengers. Biochem. J. 220:345-360.

27. Saltiel, A. R., P. Sherline, and J. A. Fox. 1987. Insulin-stimulated diacylglycerol production results from the hydrolysis of a novel phosphatidylinositol glycan. J. Biol. Chem. 262:1116-1121.

28. Truett, A. P., P. Snyderman, and J. J. Murray. 1989. Stimulation of phosphorylcholine turnover and diacylglycerol production in human polymorphonuclear leukocytes. Biochem. J. 260:909-913. 